\title{
Evaluasi Sistem Manajemen Informasi Objek Pajak dalam Pemungutan PBB-P2 di Badan Pendapatan Daerah Kota Bekasi
}

\author{
${ }^{1}$ Su'fatul Ulum Mutatun Afia, ${ }^{2}$ Cecep Wahyu Hoerudin
}

\author{
${ }^{1}$ UIN Sunan Gunung Djati Bandung, Indonesia; sufatulafia@gmail.com \\ ${ }^{2}$ UIN Sunan Gunung Djati Bandung, Indonesia; cecepwahyu@uinsgd.ac.id
}

\begin{abstract}
The Tax Object Information Management System (SISMIOP) is a management information system application that is used to help collect PBB-P2. In its implementation, it needs to be evaluated to assess how its performance. The purpose of this study is to find out how the Evaluation of the Tax Object Information Management System (SISMIOP) in Land and Building Tax Collection in Rural and Urban Cities (PBB-P2) in Bekasi City Bapenda and SISMIOP advantages and disadvantages in the PBB-P2 Collection in Bekasi City Bapenda. The research method used is a qualitative method with a descriptive approach, using interviews, observation, documentation studies, and triangulation as data collection techniques. The result of this research is the evaluation of SISMIOP in PBB-P2 Collection in Bekasi City Bapenda has a good assessment. The SISMIOP application has fulfilled all three aspects of eligibility. However, in the implementation of tax collection, the imposition of PBB-P2 tax has not been evenly distributed to the whole community because there are still unregistered tax objects and the lack of field verification team employees so that it cannot record the full potential of the Bekasi City PBB-P2.
\end{abstract}

Keywords: Management Information System, Tax Administration Management, Local Government

\section{Pendahuluan}

Kegiatan pemerintahan di Indonesia mulai dari pelaksanaan tugas pegawai negeri sampai dengan pembangunan negara sebagian besar dibiayai dari hasil pemungutan pajak yang dikenakan pada masyarakat. Pembiayaan kebutuhan negara oleh pajak diharapkan dapat meningkatkan pembangunan negara dan kesejahteraan masyarakat, dan pemungutan yang dikenakan diatur dalam Undang-Undang untuk menjamin kepastian hukum dan tata laksana pemungutan pajaknya.

Menurut Soemitro dalam (Sari, 2016) Pajak ialah pungutan yang dapat dipaksakan dari rakyat kepada Kas Negara berdasarkan atas Undang-Undang dan tidak mendapatkan jasa timbal (kontra pretasi) yang langsung dapat ditunjukkan dan yang digunakan untuk membayar pengeluaran umum. Pajak merupakan ujung tombak pembangunan suatu negara, maka dari itu pajak berkontribusi besar dalam membiayai pengeluaran negara. Banyaknya sumber pajak yang bisa dipungut akan meningkatkan pembangunan infrastruktur dan sarana fasilitas publik. Begitu juga dengan pajak daerah, meningkatkan penerimaan pajak daerah tidak hanya untuk menjalankan program pembangunan daerah saja tetapi juga untuk meningkatkan tingkat kemandirian yang menjadi titik ukur keberhasilan pelaksanaan otonomi daerah dan desentralisasi di Indonesia.

Pajak daerah adalah pajak yang kewenangannya diserahkan pada pemerintah daerah untuk memungut dan mengelolanya, pajak ini digunakan untuk menjalankan segala kegiatan kepemerintahan dan pembangunan daerah. Menurut (Mardiasmo, 2013) pajak daerah adalah 
kontribusi wajib kepada daerah yang terutang oleh orang pribadi atau badan yang bersifat memaksa sesuai dengan Undang-Undang, tidak memperoleh imbalan secara langsung dan digunakan untuk keperluan daerah. Pajak daerah merupakan sumber penerimaan terbesar dari Pendapatan Asli Daerah (PAD), semakin besar penerimaan PAD semakin tinggi pula tingkat kemandirian daerah, begitu pula sebaliknya. Berikut gambar diagram rasio realisasi PAD:

\section{Gambar 1}

\section{Gambar Diagram Rasio Realisasi PAD Kota Bekasi Tahun 2018}

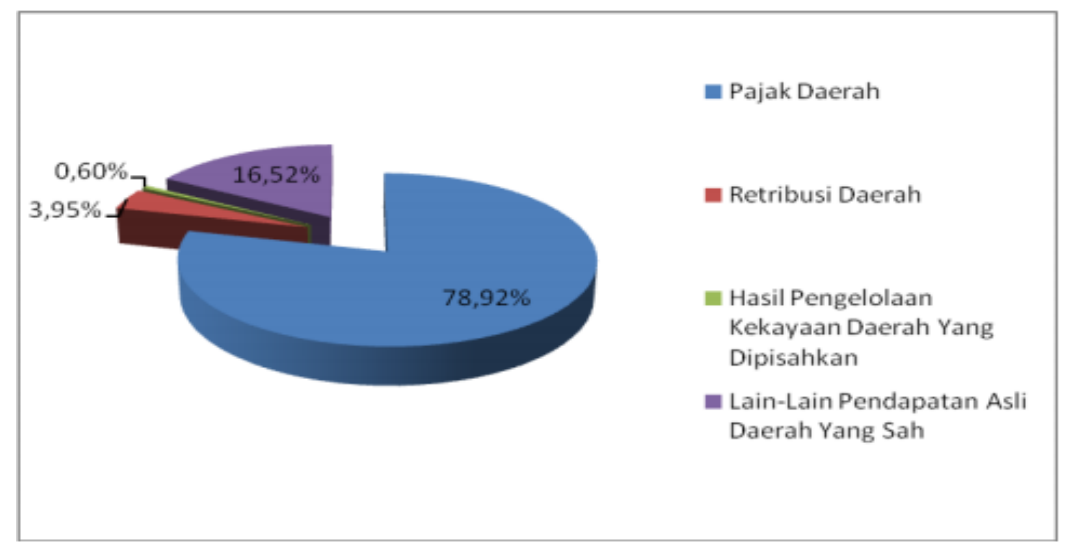

Sumber: LAKIP Bapenda Kota Bekasi, 2018

Berdasarkan gambar 1 menunjukkan bahwa tingkat kontribusi pajak daerah Kota Bekasi mencapai 78,92\%, pencapaian ini mendominasi pendapatan asli daerah Kota Bekasi. Ini menunjukkan besarnya kontribusi pajak daerah Kota Bekasi dalam penerimaan Pendapatan Asli Daerah (PAD). Pajak Bumi dan Bangunan Perdesaan dan Perkotaan (PBB-P2) adalah satu dari jenis pajak daerah yang sangat potensial untuk dilakukan pemungutan pajaknya. Pemungutan PBB-P2 dialihkan menjadi kewenangan pemerintah daerah mengacu pada Undang-Undang No. 28 tahun 2009 tentang Pajak Daerah dan Retribusi Daerah pasal 1 ayat 37, Pajak Bumi dan Bangunan Perdesaan dan Perkotaan adalah pajak atas bumi dan atau bangunan yang dimiliki, dikuasai dan atau dimanfaatkan oleh orang pribadi atau badan, kecuali kawasan yang digunakan untuk kegiatan usaha perkebunan, perhutanan, dan pertambangan.

PBB-P2 objeknya berupa bumi dan sebuah bangunan dan Wajib pajaknya adalah orang pribadi atau badan yang memiliki, menguasai atau memanfaatkan, karena hal inilah PBB-P2 menjadi pajak dengan potensi pemungutan terbesar dalam pajak daerah, pajak ini memiliki objek pajak dan subjek pajak yang berjumlah besar dan menyebar diseluruh wilayah. Berikut besarnya ketetapan dan realisasi penerimaan PBB-P2 di Kota Bekasi dapat dilihat pada tabel di bawah ini:

\section{Tabel 1}

Ketetapan dan Realisasi Penerimaan PBB-P2 Kota Bekasi

\begin{tabular}{cccc}
\hline Tahun & Ketetapan & Realisasi & Persentase \\
\hline $\mathbf{2 0 1 5}$ & 267.091 .230 .137 & 188.730 .565 .061 & $70,67 \%$ \\
\hline $\mathbf{2 0 1 6}$ & 255.084 .840 .304 & 219.513 .649 .453 & $86,06 \%$ \\
\hline $\mathbf{2 0 1 7}$ & 288.893 .088 .370 & 238.151 .302 .234 & $82,43 \%$ \\
\hline $\mathbf{2 0 1 8}$ & 362.984.866.397 & 409.240 .086 .616 & $112,74 \%$ \\
\hline \multicolumn{5}{c}{ Sumber: Bapenda Kota Bekasi (diolah Peneliti), 2020 }
\end{tabular}


Berdasarkan tabel di atas dapat dilihat bahwa realisasi penerimaan PBB-P2 pada tahun 2015 sampai 2017 tidak dapat mencapai ketetapan, yaitu memperoleh realisasi sebesar 70,67\%; $86,06 \%$; dan 82,43\%. Sedangkan pada tahun 2018 realisasi penerimaan mampu melampaui ketetapan yaitu mencapai 112,74\%. Berdasarkan dari Lakip Bapenda tahun 2018 kenaikan ini disebabkan beberapa faktor yaitu adanya penerapan regulasi penghapusan denda PBB terhadap Wajib pajak yang menunggak, melakukan verifikasi data SPPT PBB bermasalah dan sebagainya. Dalam proses pemungutannya berdasarkan Keputusan Direktur Jenderal Pajak Nomor KEP115/PJ/2002, PBB-P2 dibantu menggunakan suatu sistem informasi manajemen yang terintegritas yaitu penggunaan aplikasi SISMIOP (Sistem Manajemen Informasi Objek Pajak).

Sistem Manajemen Informasi Objek Pajak (SISMIOP) menurut (Novianti, 2014) adalah aplikasi yang terintegrasi yang ditunjang dengan penggunaan komputer untuk dapat mengolah institusi data objek dan subjek PBB mulai dari pengumpulan data, pemberian nomor identitas objek pajak (NOP), perekaman data, pemeliharaan basis data, pencetakan hasil keluaran, pemantauan penerimaan, pelaksanaan penagihan dan pelayanan. Sebagaimana yang terdapat dalam Lampiran Keputusan DJP Nomor KEP-533/PJ/2000, SISMIOP merupakan aplikasi pedoman administrasi PBB yang telah dioperasikan sejak tahun 1992 di lingkungan Direktorat Jenderal Pajak, sistem komputerisasi PBB pada awalnya dibangun dalam suatu platform sebagai berikut, menggunakan perangkat keras berbasis Personal Computer (Server), sistem operasi Unix, perangkat lunak basis data recital, dan program aplikasi SISMIOP yang dibangun menggunakan perangkat lunak Recital.

Pada tahun 1996, program aplikasi ini dikembangkan pada aplikasi lainnya seperti Sistem Informasi Geografis (SIG) PBB dan aplikasi Pelayanan Informasi Telepon (PIT), dan aplikasi tersebut terintegrasi dengan SISMIOP dan tetap menggunakan basis data SISMIOP sebagai sumber data numerisnya. sejak tahun 1997 aplikasi SISMIOP telah dikembangkan dalam perangkat lunak basis data yang dipilih oleh Departemen Keuangan RI sebagai standar pengolahan basis data. SISMIOP yang dibangun dengan basis data Oracle sejak tahun 2000 tersebut selanjutnya disebut I-SISMIOP.

Penerapan SISMIOP di Indonesia pada awalnya digunakan di pusat untuk pemungutan PBB, yaitu berdasarkan pada Keputusan DJP Nomor KEP-533/PJ/2000 pada tanggal 20 Desember 2000 Tentang Petunjuk Pendaftaran, Pendataan dan Penilaian Objek dan Subjek Pajak Bumi dan Bangunan dalam Rangka Pembentukan dan atau Pemeliharaan Basis Data SISMIOP yang sekarang telah diubah dengan Keputusan Direktur Jenderal Pajak Nomor KEP115/PJ/2002. Sejalan dengan diterbitkannya Undang-Undang No. 28 tahun 2009, dimana pemungutan PBB-P2 dialihkan ke daerah maka aplikasi SISMIOP juga digunakan di daerah karena aplikasi ini mengintegrasikan seluruh pelaksanaan kegiatan PBB. Di Kota Bekasi penerapan SISMIOP dan pelaksanaan pemungutan PBB-P2 telah dilakukan pada tahun 2013 dan pengoperasian aplikasi SISMIOP di dikelola oleh Badan Pendapatan Daerah Kota Bekasi, sebagaimana pernyataan dari hasil wawancara dengan Prakom Ahli Pertama Bidang Sistem dan Informasi Bapenda (Rabu, 26 Februari 2020, di Bapenda Kota Bekasi).

Pengoperasian SISMIOP di Bapenda Kota Bekasi membantu segala kegiatan terkait PBB-P2 salah satu manfaat yang sangat membantu dari aplikasi tersebut adalah pencetakan massal SPPT (Surat Pemberitahuan Pajak Terhutang). Pencetakan tersebut dilakukan menggunakan sistem sehingga dapat mencetak dalam jumlah yang besar. Berikut merupakan data jumlah cetak massal SPPT pertahun dari aplikasi SISMIOP adalah: 
Tabel 1

Data Jumlah Cetak Massal SPPT Kota Bekasi

\begin{tabular}{cccc}
\hline Tahun & $\begin{array}{c}\text { Jumlah } \\
\text { Kecamatan }\end{array}$ & Jumlah Cetak SPPT & Pokok (Rp) \\
\hline 2015 & 12 & 621.985 & 267.091 .230 .137 \\
\hline 2016 & 12 & 513.737 & 255.084 .840 .304 \\
\hline 2017 & 12 & 526.120 & 288.893 .088 .370 \\
\hline 2018 & 12 & 667.717 & 362.984 .866 .397 \\
\hline
\end{tabular}

Sumber: Bapenda Kota Bekasi (diolah Peneliti), 2020

Berdasarkan data di atas dapat dilihat bahwa terjadi fluktuasi pada jumlah cetak massal SPPT di Bapenda Kota Bekasi terutama pada tahun 2016 mengalami penurunan yang sangat besar dibandingkan dengan tahun sebelumnya yaitu berjumlah 513.737 SPPT dengan pokok Rp 255.084.840.304,-. Pada tahun 2017 dan 2018 terjadi peningkatan jumlah cetak massal SPPT yaitu berjumlah 526.120 SPPT dengan pokok Rp 288.893.088.370,- pada tahun 2017, dan 667.717 SPPT dengan pokok Rp 362.984.866.397,-- pada tahun 2018. Berdasarkan hasil observasi awal pada tanggal 26 Januari 2020 dengan Analisis Pemeriksaan Pajak Daerah Bapenda Kota Bekasi mengatakan bahwa jumlah data cetak massal SPPT yang naik turun dikarenakan kurangnya verifikasi data lapangan sehingga tidak dapat mendata seluruh potensi PBB di Kota Bekasi.

Kurangnya verifikasi data lapangan pada aplikasi SISMIOP mengakibatkan fluktuasi pada jumlah cetak massal SPPT, hal ini juga menyebabkan tidak terdatanya seluruh potensi pajak di Kota Bekasi. Bapenda Kota Bekasi perlu menjaga akurasi data SISMIOP dengan pemeliharaan dan penyesuaian berdasarkan kondisi yang sebenarnya dilapangan. Aplikasi SISMIOP diharapkan mampu mengintegrasikan seluruh kegiatan dalam pemungutan PBB-P2 mulai dari input data, sampai dengan menghasilkan output dan monitoring terhadap output tersebut. Berdasarkan hal ini, perlu dilakukan pengevaluasian terhadap aplikasi SISMIOP di Bapenda Kota Bekasi karena kurang validnya data jumlah cetak massal SPPT Kota Bekasi sehingga menyebabkan tidak terdatanya potensi pajak dan pemenuhan terhadap penerimaan daerah.

Permasalahan yang terjadi disebabkan karena kurang maksimalnya kegiatan pemungutan pajak pada tahun 2015-2017, hal ini dibuktikan dengan data realisasi penerimaan PBB-P2 tahun 2015, 2016 dan 2017 yang tidak mencapai ketetapan, dan kurangnya verifikasi data lapangan pada aplikasi SISMIOP sehingga menyebabkan fluktuasi pada data jumlah cetak massal SPPT dan tidak terdatanya seluruh potensi pajak di Kota Bekasi. Hal ini dibuktikan dari data jumlah cetak massal SPPT yang mengalami fluktuasi dan hasil wawancara awal dengan Ibu Annysa Subagyo pada 26-01-2020 di Kantor Bapenda Kota Bekasi.

Permasalahan di atas dapat dikaji dengan menggunakan teori mengenai evaluasi aplikasi Sistem Informasi Manajemen (Hartono, 2013) Setiap aplikasi dalam SIM perlu dilakukan pengevaluasian terhadap tiga aspek kelayakan, yaitu Kelayakan teknis, Penilaian terhadap kelayakan teknis adalah untuk mengetahui apakah aplikasi tersebut layak secara teknis untuk mengelola atau menangani data-data dan informasi yang diusulkan. Penilaian dari teknologi yang digunakan dan kemampuan pengolahan data ada aplikasi. 
Kelayakan operasional, Aplikasi dinilai dari segi kelayakan operasional untuk memeriksa apakah data-data yang digunakan sebagai input atau masukan dapat disediakan dan apakah output atau hasil keluarannya memberikan manfaat dan dapat digunakan. Selain itu, penilaian juga dilakukan pada saat aplikasi dijalankan untuk memeriksa baik-buruknya kinerja aplikasi tersebut, terutama yang berkaitan dengan proses inputting atau masukan, banyaknya kesalahan (error rate), ketepatan waktu dari dihasilkannya keluaran (output), dan penggunaan dari output tersebut.

Kelayakan ekonomis, dilakukan untuk menilai apakah biaya yang dikeluarkan untuk menjalankan aplikasi tersebut sebanding dengan manfaat yang diperoleh. SISMIOP merupakan aplikasi utama dalam pengelolaan segala data-data PBB-P2, sehingga dalam pemungutannya aplikasi ini sangat berperan penting dalam PBB-P2. Pada proses pemungutannya Pemerintah Daerah perlu memperhatikan beberapa syarat pemungutan yang harus dipenuhi. Mardiasmo (2013) mengemukakan bahwa pemungutan pajak terdapat beberapa syarat, diantaranya yaitu: Syarat keadilan, adil dalam melakukan pemungutan pajak, syarat yuridis, Undang-Undang adalah dasar hukum adanya pemungutan pajak, syarat ekonomis, perekonomian tidak terganggu, syarat finansial, pemungutan pajak dilakukan secara efisien, kesederhanaan sistem pemungutan pajak.

Administrasi publik merupakan disiplin ilmu yang mempelajari semua kegiatan yang dilakukan oleh aparatur negara untuk melaksanakan dan memaksakan kebijakan umum dan kebijakan negara. Salah satu ruang lingkup dari ilmu administrasi publik yaitu administrasi keuangan negara. Administrasi keuangan negara menurut (Anggara, 2016) yaitu semua kekayaan yang dimiliki oleh negara dan pengelolaannya dilakukan oleh pemerintah, kekayaan negara tersebut adalah semua hak yang dapat dinilai dengan uang, seperti: Pajak yang dikenakan pada warga negara, pencetakan uang kertas dan logam, dan mengadakan pinjaman paksa pada warga negara

Ruang lingkup keuangan negara dikelompokkan dalam tiga bidang pengelolaan yang bertujuan untuk mengklasifikasikan pengelolaan keuangan negara, yaitu: Bidang pengelolaan pajak, bidang pengelolaan moneter, dan bidang pengelolaan kekayaan negara yang dipisahkan. Pengelolaan pajak merupakan salah satu dari ruang lingkup administrasi keuangan negara, dimana pengelolaan pajak adalah segala kegiatan administrasi yang bertujuan untuk menjalankan kebijakan perpajakan sesuai dengan hukum yang berlaku, mulai dari pelayanan, pengawasan, pemungutan dan pembinaan. Dalam upayanya untuk meningkatkan efisiensi dan efektivitas kerja, pemerintah menerapkan Sistem Informasi Manajemen (SIM) dalam pengelolaan perpajakan.

SIM adalah suatu sistem informasi yang bekerja untuk menyajikan informasi yang nantinya dapat digunakan untuk mendukung operasi, manajemen, dan pengambilan keputusan dalam suatu organisasi. SIM juga disebut sebagai sistem peringatan manajemen (management alerting system), karena sistem ini dapat memberikan informasi berupa peringatan ataupun peluang. Salah satu aplikasi SIM yang digunakan dalam pengelolaan perpajakan yaitu SISMIOP (Sistem Manajemen Informasi Objek Pajak). SISMIOP merupakan aplikasi yang mengelola data-data seputar PBB-P2, yang salah satu manfaatnya adalah dapat memberikan informasi penting seperti ketetapan SPPT dan lainnya. Dalam pemungutan PBB-P2 SISMIOP merupakan instrumen paling penting. 
Sistem Manajemen Informasi Objek Pajak (SISMIOP) Menurut (Lambey, 2016) adalah sistem aplikasi yang melakukan pengolahan PBB-P2 pada keseluruhan aspek administrasinya, melakukan pengelolaan data komputerisasi pada objek dan subjek pajak, mulai dari pendataan, penilaian, penagihan, penerimaan atau pembayaran dan pelayanan pada wajib pajak. SISMIOP dimaksudkan untuk membuat basis data yang selalu diperbaharui dan akurat dengan menghubungkan semua kegiatan PBB-P2 ke dalam satu wadah agar lebih efisien.

Pada penelitian sebelumnya yang dilakukan oleh (Sari, 2016) dari UIN Sunan Gunung Djati Bandung, dengan Judul "Signifikansi Sistem Manajemen Informasi Objek Pajak (SISMIOP) terhadap efektifitas penerimaan Pajak Bumi dan Bangunan Perdesaan dan Perkotaan di DPPKAD Kabupaten Karawang". Masalah pada penelitian ini karena kurang efektifnya penerimaan PBB-P2, ketidak akuratan basis data, human error, dan kurangnya kesadaran Wajib pajak membayar pajak. Metode yang digunakan pada penelitian ini menggunakan pendekatan kuantitatif dengan metode asosiatif. Hasil penelitiannya yaitu: dengan menggunakan uji validitas dan reliabilitas, semua pengujian dinyatakan valid dan reliabel. Artinya terdapat hubungan signifikan yang kuat antara SISMIOP dengan efektifitas.

Pada penelitian (Lambey, 2016) Universitas Sam Ratulangi Manado, dengan judul "Evaluasi Sistem Manajemen Informasi Objek Pajak (SISMIOP) Terhadap Penerimaan Pajak Bumi dan Bangunan di Kota Bitung”. Permasalahan pada penelitian ini karena masih banyak Wajib pajak yang tidak melakukan kewajiban perpajakan dengan benar dan tepat waktu. Metode yang digunakan yaitu metode analisis deskriptif komparatif. Dan hasil dari penelitiannya menunjukkan kalau pelaksanaan Sistem Manajemen Informasi Objek Pajak (SISMIOP) di Kota Bitung telah memadai dan telah dilaksanakan dengan baik, seperti proses pelayanan yang mudah dan cepat sehingga dapat meningkatakan penerimaan PBB di setiap tahunnya. Perbedaan penelitian yaitu pada variabel keduanya dan metode penelitiannya, pada penelitian ini variabel kedua adalah pemungutan pajak dan metode penelitiannya menggunakan metode deskriptif kualitatif.

Pada penelitian (Novianti, 2014) dari Universitas Hasanuddin Makassar, yang berjudul "Penerapan Sistem Manajemen Informasi Objek Pajak (SISMIOP) sebagai sarana peningkatan pelayanan dan penerimaan Pajak Bumi dan Bangunan di Kota Makassar". Masalahnya yaitu sebelum diterapkan SISMIOP sering terjadi penyimpangan, seperti pengendapa pajak dan keterlambatan pelayanan yang dilakukan aparat setempat. Metode yang digunakan adalah deskriptif kualitatif. Hasil dari penelitiannya adalah pemaksimalan penerapan sistem ini diperlukan peralatan yang baik dan tenaga kerja yang terdidik sehingga dapat menyelesaikan masalah dengan lebih cepat seperti keberatan, pengurangan, dan balik nama. SISMIOP membuat tingkat penerimaan PBB setiap tahunnya terus meningkat karena pelayanan yang baik dan adanya penagihan yang terus menerus.

Pada penelitian (Standiford et al., 1999) dari Universitas California, dengan judul "Using GIS in Agricultur Land Assessment for Property Taxes". Metode yang digunakan menggunakan metode kuantitatif dengan pendekatan berbasis sains. Hasil penelitiannya yaitu: teknologi GIS dapat digunakan untuk menilai produktivitas lahan pertanian yang akan dikenakan pajak properti. Perbedaan penelitiannya yaitu pada penelitian ini menggunakan Sistem aplikasi GIS (Geographic Information Systems) atau sistem informasi geografi, sistem ini berfungsi untuk menilai lahan yang akan dikenakan pajak, sedangkan dalam penelitian ini menggunakan aplikasi SISMIOP, dan metodenya kuantitatif dengan pendekatan berbasis sains, walaupun tidak disebutkan secara jelas menggunakan kuantitatif tapi bisa dilihat dari penggunaan sampel yang 
diambil untuk penelitian, sedangkan pada penelitian ini, peneliti menggunakan metode deskriptif kualitatif.

Berdasarkan penelitian terdahulu yang telah dipaparkan di atas, keterkaitan penelitian yang sekarang dengan yang terdahulu adalah pada aplikasi sistem informasi manajemen perpajakan dan pada Pajak Bumi dan Bangunan. Tiga dari empat penelitian terdahulu meneliti aplikasi yang sama yaitu aplikasi SISMIOP, diantaranya yaitu penelitian dari Kartika Purna Sari (2016), Rika Dwi Aprianty dan Robert Lambey (2016), dan Pratiwi Novianti (2014). Sedangkan pada penelitian terdahulu yang keempat yaitu pada penelitian Richard B. Standiford, James W. Bartolome, William Frost \& Neil McDougald (2009), penelitian ini juga mengenai aplikasi sistem informasi manajemen perpajakan namun berbeda aplikasi. Pada penelitian ini, peneliti akan melakukan evaluasi pada aplikasi SISMIOP menggunakan teori Hartono (2013) yang tidak digunakan pada keempat penelitian terdahulu, dengan melakukan evaluasi aplikasi terhadap tiga aspek kelayakan, yaitu kelayakan teknis, operasional dan ekonomis. Maka dari itu, tujuan dari penelitian ini yaitu untuk mengetahui bagaimana Evaluasi Sistem Manajemen Informasi Objek Pajak (SISMIOP) dalam Pemungutan Pajak Bumi dan Bangunan Perdesaan dan Perkotaan (PBB-P2) di Bapenda Kota Bekasi dan faktor kelebihan dan kekurangan SISMIOP dalam Pemungutan PBB-P2 di Bapenda Kota Bekasi.

\section{Metode Penelitian}

Penelitian ini menggunakan pendekatan kualitatif dan jenis penelitian deskriptif. Penelitian ini dimaksudkan untuk memberikan pemahaman secara deskripsi yang dapat menjelaskan secara mendalam dan menyeluruh terhadap evaluasi aplikasi SISMIOP yang digunakan dalam kegiatan pemungutan PBB-P2 di Bapenda Kota Bekasi, dalam pendekatan kualitatif, peneliti menghimpun data-data yang terkumpul lalu melakukan pengamatan secara seksama yang akan menghasilkan penggambaran yang utuh dan komprehensif.

Teknik pengumpulan data menggunakan teknik observasi, wawancara, dan studi dokumentasi. Pada observasi, peneliti melakukan pengamatan langsung ke kantor Bapenda Kota Bekasi pada bulan Januari sampai bulan Maret 2020. Pada wawancara peneliti melakukan wawancara dengan tiga informan dari Bapenda Kota Bekasi, yaitu (1) Prakom Ahli Pertama Bidang Sistem dan Informasi Bapenda Kota Bekasi, (2) Prakom Terampil Pelaksana Bidang Sistem dan Informasi Bapenda Kota Bekasi, dan (3) Analisis Pemeriksaan Pajak Daerah Bidang Pengelolaan Pendapatan Daerah Bapenda Kota Bekasi. Pada studi dokumentasi, peneliti menggunakan buku, jurnal, skripsi, laporan, dokumen, angka-angka dan gambar-gambar yang berhubungan dengan penelitian.

Teknik analisis data yang digunakan dalam penelitian ini menggunakan model Miles dan Huberman (Silalahi, 2012) yaitu analisis data yang mencakup tiga alur kegiatan dan dilakukan secara bersamaan, alur dari ketiga kegiatan ini merupakan proses atau siklus dan interaksi yang saling berhubungan dan dilakukan sebelum, selama dan sesudah mengumpulkan data. Kegiatan ini dijalankan secara sejajar untuk membentuk pengetahuan umum yang disebut analisis, yaitu reduksi data, penyajian data, dan menarik kesimpulan. Selain itu, peneliti juga menggunakan teknik analisis triangulasi yang memadukan berbagai sumber data yang diperoleh peneliti sehingga tingkat keabsahan hasil penelitian lebih tinggi. 


\section{Hasil dan Pembahasan}

Berikut adalah hasil dan pembahasan dari penelitian Evaluasi Sistem Manajemen Informasi Objek Pajak (SISMIOP) dalam Pemungutan Pajak Bumi dan Bangunan Perdesaan dan Perkotaan (PBB-P2) di Badan Pendapatan Daerah Kota Bekasi: Pada aspek kelayakan teknis, teknologi ataupun sistem yang tersusun sudah mendukung aplikasi sehingga aplikasi dapat berjalan dengan baik sejak dialihkan ke daerah yaitu pada tahun 2013 dan cukup membantu proses pekerjaan pemungutan PBB-P2, teknologi yang dibutuhkan dalam mendukung aplikasi mudah digunakan. Dalam hal kecepatan pengelolaan data-data aplikasi ini sudah cukup memadai meskipun besarnya database yang dimiliki sedikit memperlambat prosesnya. Dan hambatan teknis dalam menjalankan aplikasi SISMIOP yaitu gangguan jaringan internet yang dapat memperlambat kecepatan aplikasi SISMIOP, penuhnya pemakaian harddisk dan RAM karena besarnya database dan log yang masuk setiap hari, kurang fleksibelnya sistem desktop terutama jika terdapat pembaharuan menu dan human error yang menyebabkan error system. Namun kendala teknis tersebut dapat diperbaiki sehingga aplikasi SISMIOP dapat digunakan dengan baik.

Kelayakan operasional aplikasi SISMIOP dari mulai input, operasionalisasi aplikasi, output dan manfaat dari penggunaan hasil keluaran telah berjalan dengan baik, namun memiliki beberapa kendala yang masih dapat diperbaiki dan tidak menghambat tercapainya tujuan penggunaan SISMIOP, yaitu human error dalam penginputan data atau dalam mencetak jumlah dari output, kendala dalam proses cetak hasil keluaran seperti rusaknya hardware untuk mencetak seperti printer dan kertas. Penggunaan hasil keluaran dari SISMIOP sudah dimanfaatkan secara efektif dan akan terus dikembangkan menjadi lebih baik seperti mengembangkan SPPT untuk pajak tunggakan beberapa tahun ke bawah.

Gambar 2

\section{Proses Input, Proses, dan Output Data}

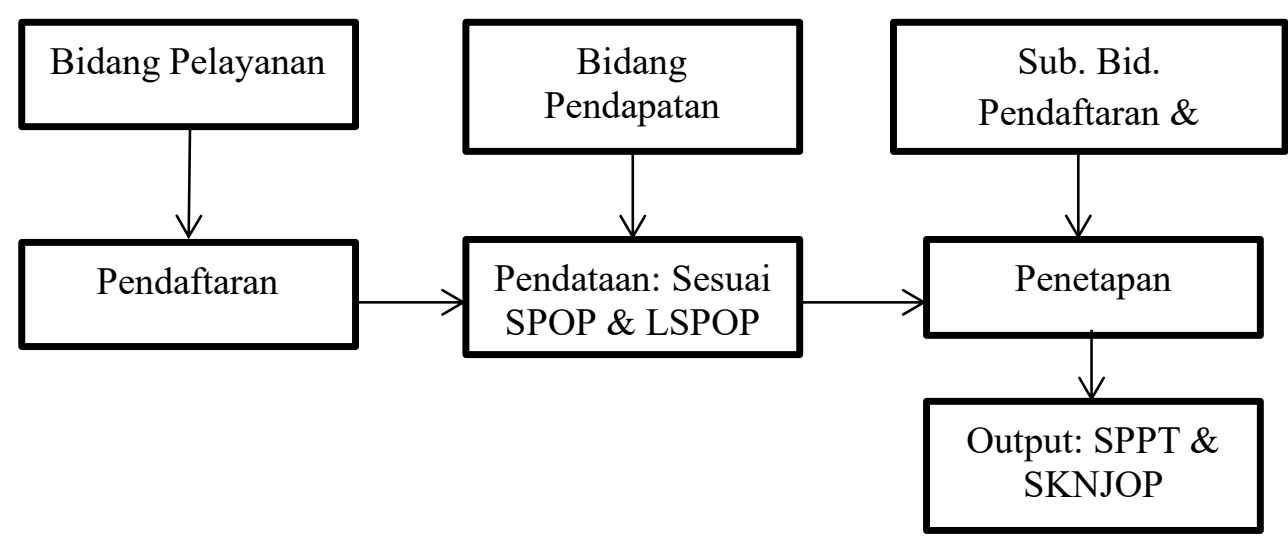

Sumber: diedit oleh peneliti berdasarkan hasil wawancara, 2020

Dari aspek kelayakan ekonomis, aplikasi SISMIOP layak secara ekonomis karena biaya yang dikeluarkan untuk membangun dan pemeliharaan aplikasinya sebanding dengan hasil yang diberikan, hasil dari pemungutan PBB-P2 setiap tahunnya bisa mencapai sekitar 400 Milyar Rupiah sedangkan biaya yang digunakan untuk pemeliharaan aplikasi sekitar 30 Juta Rupiah, pengeluaran yang digunakan untuk pemeliharaan tersebut merupakan biaya yang murah. Selain itu, juga karena SISMIOP merupakan instrumen utama dalam pengelolaan PBB-P2 sehingga 
aplikasi tersebut sangat membantu kinerja pengolahan PBB-P2. Aplikasi SISMIOP juga memberikan manfaat lebih seperti memudahkan pekerjaan dengan system by system dan dapat meningkatkan produktivitas kerja yang juga harus diimbangi dengan operator yang handal.

Aplikasi SISMIOP adalah alat utama dalam pengadministrasian pemungutan PBB-P2, dan dalam pelaksanaan pemungutan pajaknya di Bapenda Kota Bekasi perlu memenuhi syarat pemungutan pajak menurut teori pemungutan pajak Mardiasmo (2013) sebagai berikut. Pada syarat keadilan, pelaksanaan pemungutan PBB-P2 di Kota Bekasi telah memenuhi kedua indikator, yaitu indikator adil dalam perundang-undangan dan adil dalam pelaksanaan pemungutan. Pemungutan PBB-P2 mengacu pada undang-undang untuk mengatur dan menentukan tarif pajak yang dikenakan pada Wajib pajak, meskipun pengenaan pajaknya belum merata karena masih terdapat objek pajak yang belum terdaftar. Dalam pelaksanaan pemungutan PBB-P2 Wajib pajak dapat mengajukan permohonan ke petugas sesuai dengan yang diinginkan mereka dengan ketentuan-ketentuan tertentu. Pada syarat yuridis, petugas yang melakukan pemungutan sudah memahami SOP pemungutan pajak dan memahami Peraturan Daerah dan Peraturan Walikota yang mengatur tentang pemungutan pajak, dan dalam pelaksanaan pemungutannya di Kota Bekasi sudah sesuai dengan payung hukum yang berlaku.

Syarat ekonomis pada pumungutan pajak dimaksudkan agar pemungutan pajak tidak mengganggu perekonomian masyarakat, tarif yang diambil untuk dipungut sesuai dengan objek pajak yang dimiliki oleh Wajib pajak dan besarnya telah diatur dalam UU nomor 28 tahun 2009 tentang Pajak Daerah dan Retribusi Daerah dan Peraturan Daerah Kota Bekasi nomor 10 tahun 2019, agar tidak mengganggu perekonomian Wajib pajak harus mengatur kondisi perekonomiannya karena besarnya pajak telah ditentukan dalam Undang-Undang dan Peraturan daerah. Pada syarat finansial dimaksudkan untuk menekan biaya pemungutan pajak menjadi lebih rendah dari hasil pemungutannya. Bapenda telah bekerja sama dengan beberapa Bank di Indonesia agar dapat melakukan pembayaran pajak via transfer sehingga Wajib pajak tidak dikenakan biaya pemungutan. Selain itu juga bekerja sama dengan minimarket dan jika melakukan pembayaran pajak melalui minimarket Wajib pajak akan dikenakan biaya admin.

Sistem pemungutan pajak harus sederhana, Undang-Undang perpajakan yang baru telah memenuhi syarat ini dan di Bapenda Kota Bekasi juga pemungutannya sudah lebih sederhana dan tidak rumit. Teknologi yang digunakan untuk membantu petugas pemungutan juga lebih canggih sehingga lebih memudahkan. Dan saat SPPT telah terbit masyarakat sudah sadar untuk melakukan pembayaran pajak yang terhutang.

Kelebihan aplikasi SISMIOP yaitu merupakan satu-satunya aplikasi yang digunakan untuk mempermudah pemungutan PBB-P2 di Indonesia dan masih handal digunakan sampai sekarang, membantu pekerjaan dengan system by system dan dapat menyimpan semua data base PBB yang sangat besar. Adapun kekurangannya yaitu karena aplikasi SISMIOP berbasis desktop belum berbasis web sehingga jika ada pembaharuan menu harus melakukan copy dari komputer satu ke komputer yang lain, dan karena berbasis desktop aplikasi hanya bisa dibuka di komputer. Selain itu, karena aplikasi ini basisnya oracle jadi harus orang dengan keahlian menggunakan oracle yang dapat merubah (customise) menu SISMIOP. 


\section{Gambar 3. \\ Tampilan awal aplikasi SISMIOP}

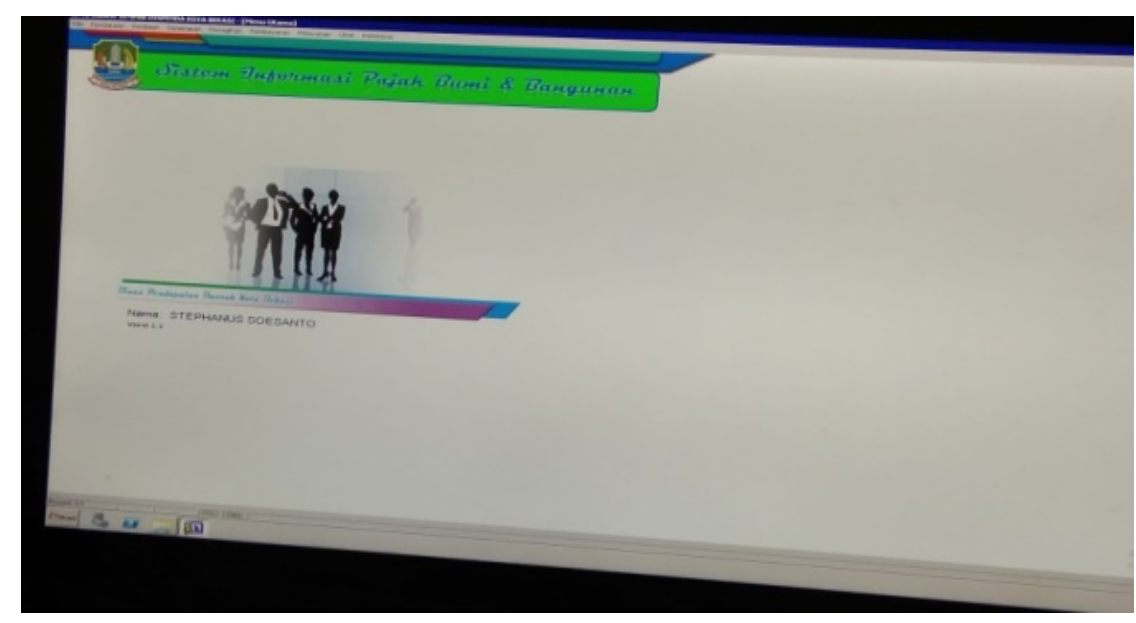

Sumber: Bidang Sistem dan Informasi Bapenda Kota Bekasi

\section{Simpulan}

Peneliti menarik kesimpulan bahwa evaluasi sistem manajemen informasi objek pajak (sismiop) dalam pemungutan PBB-P2 di Bapenda Kota Bekasi memiliki penilaian yang sudah baik. Pertama, dari aspek kelayakan teknis cukup baik karena teknologi yang tersedia dan sistem yang tersusun sudah mendukung aplikasi sehingga aplikasi SISMIOP dapat digunakan dengan baik. Kedua, dari aspek kelayakan operasional memiliki penilaian kinerja yang baik, hal ini dikarenakan mulai dari proses input, operasionalisasi aplikasi, output dan penggunaan output telah berjalan dengan baik dan sudah dimanfaatkan secara efektif dan akan terus dikembangkan menjadi lebih baik. Ketiga, dari aspek kelayakan ekonomis aplikasi SISMIOP dinilai layak secara ekonomis karena hasil yang diberikan sebanding dengan biaya awal pembangunan aplikasi dan pemeliharaan, dan juga karena memberikan manfaat lebih dengan mempermudah pekerjaan pemungutan pajak dengan system by system. Dan dalam pemungutan PBB-P2 aplikasi ini sudah membantu memenuhi kelima syarat pemungutan pajak. Pertama syarat keadilan, pemungutan mengacu pada undang-undang untuk mengatur dan menentukan tarif pajak yang dikenakan, namun pengenaan pajak PBB-P2 belum merata ke seluruh masyarakat karena masih terdapat objek pajak yang belum terdaftar dan kurangnya pegawai tim verifikasi lapangan sehingga tidak dapat mendata seluruh potensi PBB-P2 Kota Bekasi. Kedua syarat yuridis, pelaksanaan sesuai SOP, Perda dan Perwal. Ketiga syarat ekonomis, masyarakat dapat mengatur perekonomiannya sendiri karena tarif yang diambil untuk dipungut sesuai dengan objek pajak yang dimiliki oleh Wajib pajak dan besarnya telah diatur dalam UU dan Perda. Keempat syarat finansial, sudah berjalan dengan efisien karena Bapenda bekerja sama dengan Bank sehingga Wajib pajak tidak dikenakan biaya pemungutan pajak. Kelima Sistem pemungutan pajak harus sederhana, telah dipenuhi oleh UU perpajakan yang baru dan pelaksanaan pemungutan tidak rumit dan didukung teknologi yang modern. 


\section{Referensi}

Anggara, S. (2016). Administrasi Keuangan Negara. Pustaka Setia.

Hartono, B. (2013). Sistem Informasi Manajemen Berbasis Komputer. Rineka Cipta.

Keputusan Direktorat Jenderal Pajak KEP-533/PJ/2002 dan Surat Edaran Direktorat Jenderal Pajak SE-60/PJ/2001 Tentang Petunjuk Pendaftaran, Pendataan dan Penilaian Objek dan Subjek Pajak Bumi dan Bangunan dalam Rangka Pembentukan dan atau Pemeliharaan Basis Data Sistem Manajemen Informasi Objek Pajak (SISMIOP).

Lambey, R. D. A. dan R. (2016). Evaluasi Sistem Manajemen Informasi Objek Pajak (SISMIOP) Terhadap Penerimaan Pajak Bumi dan Bangunan di Kota Bitung. EMBA, 4 No. 1, 781790.

Mardiasmo. (2013). Perpajakan Edisi Revisi. ANDI.

Novianti, P. (2014). Penerapan Sistem Manajemen Informasi Objek Pajak (SISMIOP) Sebagai Sarana Peningkatan Pelayanan dan Penerimaan Pajak Bumi dan Bangunan di Kota Makassar.

Pedoman Umum Pengelolaan Pajak Bumi dan Bangunan Perdesaan dan Perkotaan. (2014). Kementerian Keuangan Republik Indonesia Direktorat Jenderal Perimbangan Keuangan.

Peraturan Walikota Bekasi nomor 14 tahun 2019 tentang Perubahan Atas Peraturan Walikota Bekasi Nomor 66 Tahun 2016 Tentang Kedudukan, Susunan, Organisasi, Tugas Pokok Dan Fungsi Serta Tata Kerja Pada Bapan Pendapatan Daerah Kota Bekasi.

Peraturan Direktur Jenderal Pajak Nomor PER-12/PJ/2010 Tentang Nomor Objek Pajak Bumi dan Bangunan.

Sari, D. (2016). Konsep Dasar Perpajakan. Refika Aditama.

Sari, K. P. (2016). Signifikansi Sistem Manajemen Informasi Objek Pajak (SISMIOP) terhadap efektifitas penerimaan Pajak Bumi dan Bangunan Perdesaan dan Perkotaan di DPPKAD Kabupaten Karawang. UIN Sunan Gunung Djati Bandung.

Sayekti, S. (2010). Pengaruh Aplikasi Sistem Manajemen Informasi Objek Pajak (SISMIOP) Terhadap Kinerja Aparatur Pajak (Studi Kasus pada KPP Pratama di Wilayah Jakarta Selatan).

Silalahi, U. (2012). Metode Penelitian Sosial. Refika Aditama.

Standiford, R. B., Bartolome, J. W., Frost, W., \& McDougald, N. (1999). Using gas in agricultural land assessment for property taxes. Geographic Information Sciences, 5(1), 47-51. https://doi.org/10.1080/10824009909480513.

Surat Edaraan Direktorat Jenderal Pajak SE-07/PJ/2014 Tentang Pedoman Pelaksanaan Pengalihan Pajak Bumi dan Bangunan Perdesaan dan Perkotaan Sebagai Pajak Daerah.

Undang-Undang No. 28 Tahun 2009 tentang Pajak Daerah dan Retribusi Daerah. 